\title{
THE RUSSIAN RITUAL YEAR AND FOLKLORE THROUGH TOURIST ADVERTISING
}

\section{IRINA SEDAKOVA}

This article analyzes the ritual year in modern Russia as reflected in tourism spam letters circulated between 2005 and 2012. These texts are the main source of data for this study because they illustrate major tendencies in governmental, commercial, and individual attitudes towards Russian traditional customs and official holidays. They also demonstrate how local heritage is being maintained and reconstructed, and how new myths and customs are appearing and developing to suit the needs of domestic tourism, a special ethnographic calendrical type.

Keywords: Russia, ritual year, carnival, advertising, tourism anthropology, semiotics.
Članek analizira praznično leto $v$ moderni Rusiji, kot ga odsevajo turisticna oglasna sporocila med letoma 2005 in 2012. Tovrstna besedila so glavni vir podatkov za to študijo, saj odsevajo pomembnejse tendence vladnih, komercialnih in individualnih pogledov na ruske tradicionalne sege in uradne praznike. Prikazujejo tudi, kako se obranja in rekonstruira lokalna dedišcina in kako se pojavljajo in razvijajo novi miti in rituali, kot jih zahtevajo potrebe domačega turizma.

Ključne besede: Rusija, praznično leto, pust, oglaševanje, turistična antropologija, semiotika.

\section{INTRODUCTION}

This article focuses on the revitalization and re-invention of calendrical ritual celebrations in modern Russian provincial cities as a reciprocal process introduced by local authorities and tourist developers to motivate domestic tourists. This study touches on many subdisciplines within anthropology, folklore, and linguistics. The topic partly fits into the anthropology of tourism, an academic discipline well established in Europe and the U.S. (core works are published in Smith 1989, Nash 1996, and Nash 2007 et al., but not yet presented in Russian academic investigation and teaching ${ }^{1}$ ). Since the 1990 s, tourism has been a booming industry in post-Soviet Russia. It started with international destinations, such as vacationing in Turkey and Egypt, and culture-based trips in Europe, whereas domestic tourism as such was not very popular. Now, in the second decade of the twenty-first century, domestic tourism is rapidly burgeoning and has become very fashionable even among young people that ten years earlier would have preferred to go abroad on vacation instead of staying in Russia and being a domestic tourist. The major types of tourism as designated by Valene Smith (1989: 4-5) are ethnic, historical, cultural, environmental, religious, and recreational. During the last decade, of course, many subtypes have developed

1 For some notes on the anthropology of tourism in Russia, see Gurin (2004). 
(sport, culinary, etc.) and also an umbrella type: heritage tourism (Dallen \& Boyd 2003; Dallen 2011). In modern Russia I speak of combined types of domestic tourism, which includes diverse tourist activity, but the program almost obligatorily has an ethnic event, when the trip is timed to coincide with a particular date in the ritual year. I refer to this type of tourism as ethnographic calendrical tourism.

The reasons for choice of a calendrical feast from the ritual year (the Christian calendar, state holidays, and other celebrations) and giving local flavor to it as a means to attract tourists have never been studied in Russia. Tourism discourse is a small part of a larger trend of rearranging time in space in the country, erasing the dominant Soviet past, reevaluating historical and religious facts, self-identification, and economic development. Touristifying pilgrimage, commercializing culture, and creating a seasonal aspect for advertising (Santino 1996) are processes that are well known in the West, but are comparatively new in postcommunist countries. The forms of Russian tourist advertising that often arrive as spam letters are also very specific and unique. ${ }^{2}$

\section{SPAM LETTERS FROM TOURIST AGENCIES}

This article is a limited study, and so I limited the material I used. I analyze only one genre: the advertisements that I have received as e-mail spam letters. Occasionally I refer to the internet sites that the e-mails refer to and to other sources, but I do not take them into account on the whole because the stylistics of a spam letter and official information are very different. ${ }^{3}$ Another restriction concerns geography: I mostly look at central Russian cities.

In 2005, spam letters with an invitation to visit a Russian city or village started arriving by the dozen. The first letters I received offered a potential visitor the opportunity to make a cultural trip to a local area in central Russia known as the Golden Ring (the cities of Vladimir, Suzdal, Novgorod, Yaroslavl, etc.). Even during Soviet times, these cities were known for the beauty of their Russian ecclesiastical medieval architecture and were the main attraction for Russian and foreign tourists. The first tourist spam advertisements accentuated the outstanding architectural heritage:

2 I would like to thank the organizers and the participants of the conference of the SIEF working group "The Ritual Year," which took place in Ljubljana 11-13 November 2011 with the title "Researchers and Performers Co-Designing Heritage." During the discussion many questions arose, and they helped me draw parallels and clarify theoretical and practical reasoning for this article. Not a single researcher in the conference hall had received or seen tourism spam letters in their countries. Even other former Soviet Republics such as Ukraine and the Baltic states do not have such letters, which is unusual because, as Arūnas Vaicekauskas puts it, the tendency of these young countries is to copy many trends that are taking place in Russia.

3 The question of correlation between the spam letters and corresponding Internet sites also arose in the discussion at the conference in Ljubljana. 
Example 1. Bell meeting in Suzdal

We invite you to take part in a magnificent one-day trip to Suzdal, which long ago was the capital of the kingdom of Rostov-Suzdal. Today Suzdal is widely known as an open-air museum that preserves medieval architecture.

Other spam letters offered the opportunity to visit religious sites, emphasizing the key notions of Russianness (Orthodoxy, the soul, etc.):

Example 2. Sergiyev Posad: Chernigov's hermitage.

Sergiyev Posad is the soul of Russia!

The city is famous firstly for its Trinity Lavra of Saint Sergius (TroitskoSergievskaya - the seminary), thanks to which it is often called the capital of Russian Orthodoxy, or the Russian Vatican. You will visit the Lavra, the gem of the Golden Ring. You will see the famous sacred objects: icons, churches, old monuments. An excursion is organized to the Chernigov hermitage: a secluded active hermitage with underground cells and churches, the center of strict spiritual monasticism, established in the middle of the nineteenth century.

Example 3. Zvenigorod: New Jerusalem

A unique excursion to the most beautiful region near Moscow, the city of Zvenigorod: the Russian Switzerland. We will visit Golgotha, the Garden of Gethsemane, and the Church of Resurrection on the Holy Sepulcher. You do not need to apply for a visa and to buy an airline ticket to see the sanctuaries of Palestine and Jerusalem. This is all included in our excursion.

Apart from cultural, religious, and ecological tourist trips, other excursions were offered. Increasingly more local features started to appear in these letters, sometimes having to do with folk religion. The importance of these texts can be proved by the case of the city of Murom, which shows how the local cult of saints Peter and Theuronia has grown into a national celebration (see below):

Example 4. We invite you to ancient Murom

You will be welcomed by the hero of the folklore bylinas, Ilya Muromets, who will tell you the old legends of Murom. You will hear the story of the patrons of the families of Saints Peter and Theuronia and will see their relics in the monastery. Thousands of people come here looking for a real miracle. You will be surprised yourselves to find out that the atmosphere in your family has changed for the better, love and understanding will come back to your house. Somebody will come back with his/her "other half." 
In 2005 and 2006 the variety of trips started to grow, and increasingly more ethnic elements began to appear in the spam letters and correspondingly at the tourist sites. For example, a letter offering pre-Christian rituals and recreation in natural settings sounded very attractive:

Example 5. Ancient Slavic magic tour

This is a three-day trip to Smolenskoe Poozerje national park, including a visit to Lake Sapsho, which is only three hours by car from Moscow. Since childhood we have been tempted by the undiscovered. How many secrets and mysteries are in the land we know? Here you will definitely find inner tranquility, a deep understanding of nature, and harmony with our world. Every participant in this trip will have the chance to approach a real secret, to sit in a tent dressed in deerskins, to meet a kind shaman, to go for a walk in a nature reserve, to drink tea with herbs from the forest, to relax in a steamy Russian sauna, to show one's talent by singing along with a guitar near the fire, and simply to have a rest, while your body and soul relax in harmony with nature.

The stylistics of the spam letters also vary greatly. In addition to short informative texts, there are longer poems, like this one, describing the May tour Chéz Baba Yaga in Uglich:

Example 6.4

Эй, весёльий друг турист!

Съезди в Углич, оттянись!

Что за жизнь без приключений?

Просто скука, а не жизнь...

Познакомишься с Ягой,

будет там и Домовой,

дядька Леший с бородой

пообщается с тобой.

Оглядишь монастыри

и снаружи и внутри,

древний Углич всё откроет,

Мыликин с “Мылшью” познокомит

и устав от тех трудов

- на пикник в лесу готов?
Hey, my dear tourist friend!
Go to Uglich and relax!
What's life like without drive?
It is boring. It's not life!
You will meet up with Yaga
And the Domovoy himself,
Uncle Leshiy with a beard
Will entertain you a lot.
You will visit the monasteries
From the outside and inside,
Ancient Uglich will open everything for you,
Myshkin will acquaint you with the Mouse
When you get tired of sightseeing
Are you ready for a picnic in the woods?

I have presented several types of tourist spam letters that I received in 2005 and 2006. At that time, my major research project was aimed at investigating quotations in modern Russian discourse and, because I discovered some interesting cognitive and axiological points

4 The Russian is retained here. 
in these texts, I decided to keep saving them. With the passage of time and the quantity and quality of the spam letters growing, I realized that the texts I was receiving were modified according to the ritual year and offered local versions of ethnographic calendrical tourism. Every new year and festive circle brought in information about new loci and new seasonal celebrations, depicted in an increasingly sophisticated style (on the improvement and impressive creativity of the copywriters of Russian internet sites, see Sedakova 2010).

Thus, apart from the value of the spam letters as a genre, these texts proved to be important documents that reflect the entire process of rearranging time and space in modern Russia. The significance of such a text was emphasized by the late academician Vladimir Toporov, who studied not only many ancient texts but also small contemporary notes such as street graffiti, short texts on the grave of the Russian Saint Xenia of Saint Petersburg, and so on. He called these texts odnodnevki - texts that survive one day-and pointed out: "The short period of their life is opposed to the fact that time not only wipes away the texts, but also produces new ones, according to the old patterns. Not a single ethnological piece of research can pretend to be a broad enough study if it does not take into account such texts. Moreover, they create myths themselves ..." (Toporov 1992: 252). This idea is supported and complemented by many scholars and is also very valuable for sociolinguists. The language of tourism (on this concept, see Dann 1996, 2002), which is at the core of my research, consists of such texts, based on precedent texts and new myths. Through pictures, brochures, and other media, the language of tourism attempts to seduce millions of people into becoming tourists and subsequently to control their attitudes and behavior (Smith, Waterton, \& Watson 2012).

\section{CALENDRICAL TIME AND PLACE, OR PLACE AND CALENDRICAL TIME: CARNIVAL}

Investigation of the spam letters proves the idea of reciprocal influence of time and space, and it also shows the remembrance of the old and formation of new chronotopes in modern Russia. Many cities had to start from the very beginning: with the name, which is the key to historical memory and culture, and also an important source for inventing ritual tradition and mythology. 5 Since 1990, a process of renaming cities (giving them old

5 To give just two examples of the correspondence between the name and the local developments aiming partly to attract tourists: the city of Myshkin (resembling the Russian word for 'mouse') was one of the first to play with its name, establishing a private mouse museum. Local entrepreneurs also used the image of the mouse (produced in the city in all forms and of all materials) to invite tourists to come to the city and buy souvenirs for the coming Chinese year of the rat. Another example is the city of Tambov. Due to the Russian saying "Tambov's wolf is your friend" as a reply to addressing somebody as "friend," tourism developers organized a wolf museum. All of these examples were taken from the spam letters and then double-checked in the official tourist information. For more examples on development of mythology and folklore in the provincial cities as part of the project Folklore Map of Russia, see below. 


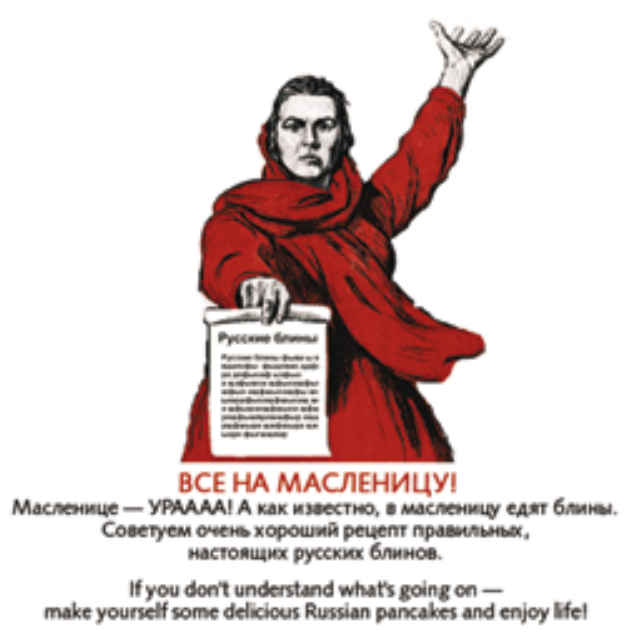

Figure 1. Internet-advertisement of the Shrovetide (Crepes) week in Moscow. A commercial remake of the well-known Soviet poster by Irakliy Toidze (1941). The author of the remake is unknown. 2004.

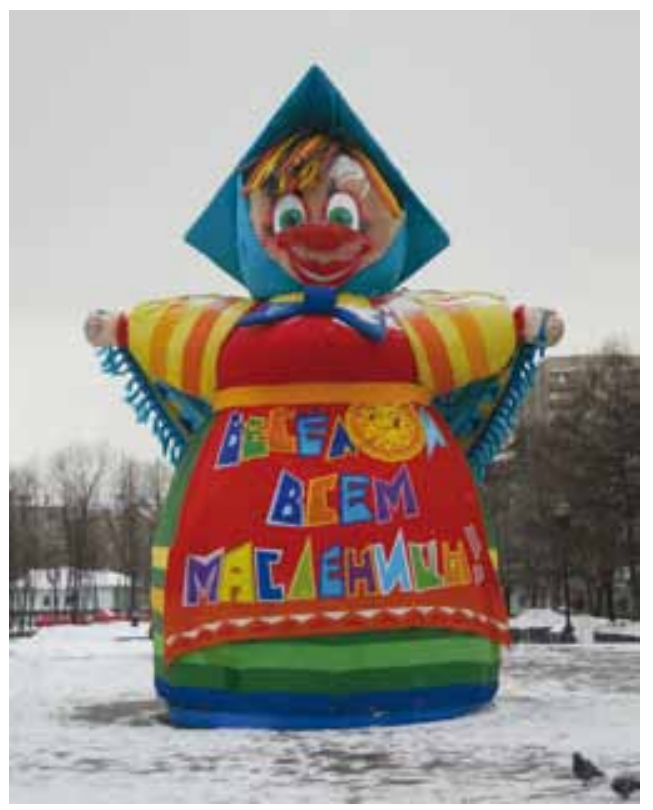

Figure 2. Figure of Maslenitsa (the Carnival) in Pushkin Square, Moscow. 2011. (Photos by I. Sedakova) pre-revolutionary names) has been taking place: Leningrad became Saint Petersburg, Sverdlovsk became Yekaterinburg, Gorky became Nizhny Novgorod, Kuybyshev became Samara, Kalinin became Tver, and so on. Along with the process of renaming, the process of developing the local identity started, and one of the many sources for remembering the past and presenting it as a living tradition is the ritual that is an important part of many traditional spheres (be it calendar holidays with performances and carnivals, or folklore with its heroes, music and dance, crafts, etc.).

Tourist spam letters show how the tours have been adjusted to the major and minor points in the ritual year, offering the specific attractions of the tourist destination. Meanwhile, the local ritual system met the needs of tourism and local people and transformed the ritual and mythological systems as well.

The ritual year as such in the spam letters I have been receiving started with Shrovetide week, known as Maslenitsa in Russian. This feast was not abolished in the USSR, even in the cities. Whereas in rural areas the entire week kept the names of the days and specific rituals-games, songs, and dances with the final burning of the figure of Maslenitsa-in the cities the dominating idea was a gastronomic one: eating crepes. After perestroika, carnival turned into a must. Now there is entertainment and crepes, the figure of Maslenitsa appears ${ }^{6}$ on time in the centre of each city, the crepes are served on the street even in

6 Crepes for carnival, and bread and cheese for Easter are very important basic culinary components, which proved to be very stable, having survived during the atheist Soviet era. An impressive use of the well-known poster redone for Maslenitsa (Figure 1). 


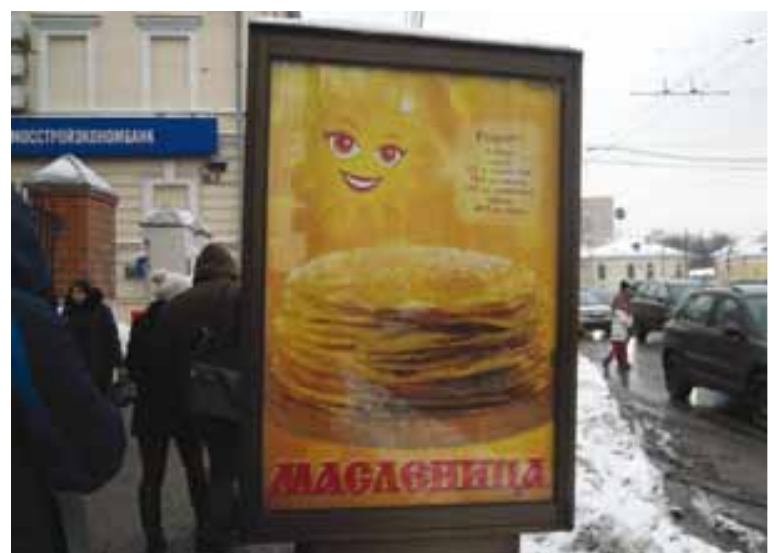

Figure 3. Street bill-boards in Moscow. 2011.

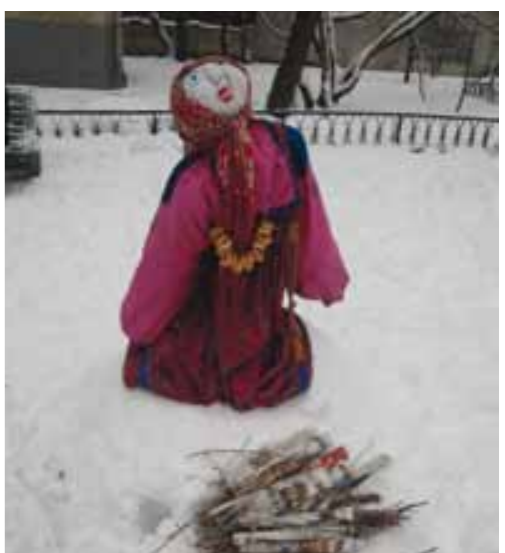

Figure 5. The figure of the Maslenitsa (the Carnival) before being put on fire in Nikitskaya street, Moscow. 2011.

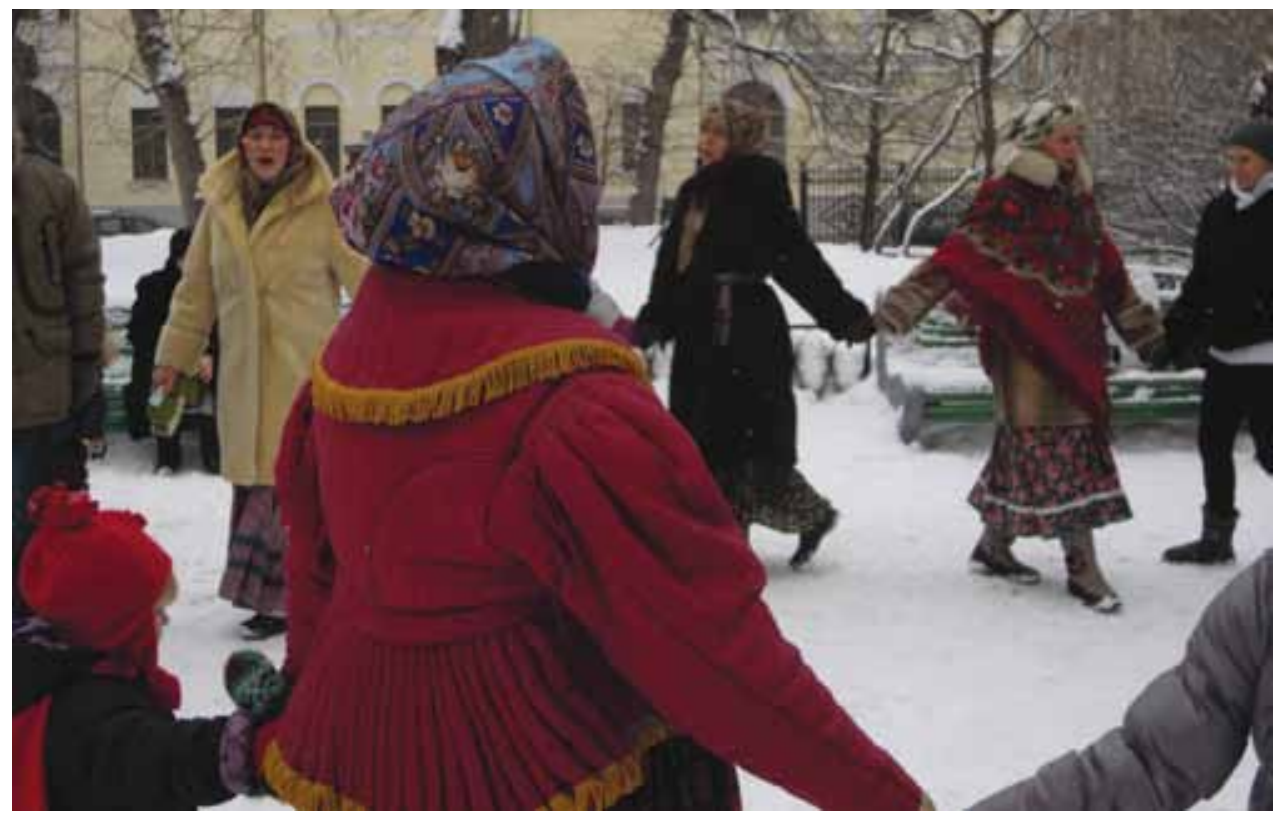

Figure 4. Street performance by folk group Nikitskaya in Nikitskaya street, Moscow. 2011.

Moscow (see Figures 2 and 3), and there are many street performances, some of them really authentic (see Figures 4 and 5).

Carnival gives the tourism entrepreneurs a very good opportunity to attract visitors: each tour includes some local specific form of the feast, mostly interactive entertainment, whereas crepes are the main culinary point of attraction. In 2006, I counted three dozen spam letters that were invitations to carnival tours in various places. In 2012 there were several hundred. 
I exemplify the most important ideas about the local tourist celebration that the spam letters present. Some of the letters simply change the title of the text and insert bits of ritual information into the usual "out of season" content.

Example 7. Wild carnival in the amazing region of Karelia

This corner of nature and resort does not need to be advertised. The winter will give you the most exclusive feast of the year. Russian carnival is famous for its charm. You will meet primordial inhabitants of the Karelian woods in their natural environment: bears with bear cubs, northern deer, elks. You'll be breathing the incomparable air of the Karelian woods. You will visit daughter-in-law parties and you'll try national Karelian food. A visit to the unique Doll's House private gallery is included in the price. Relax and enjoy.

Others emphasize carnival and give substantial information about it, but also keep the main historical program for the vicinity as such.

Example 8. Carnival is coming!!!!!! Vologda, Kirillovo, Ferapontovo

We invite you to say goodbye to winter and to welcome the spring-the Beauty in the very heart of Russia, in the ancient Russian cities of Vologda, Kirillovo, and Ferapontovo, which used to be the gates to the north. Tsar Ivan the Terrible used to choose these lands for his recreation. Many important historical and cultural events are connected with these cities. Vologda lace-making is known worldwide. These cities are famous for their Shrovetide festivities.

Nowadays, when interactive tourism is booming, special carnival performances turn into the main tourist attraction. The text below shows a specially written fake-lore scenario that includes authentic features of carnival such as games and crepes, but also mentions some evil spirits that have nothing to do with the traditional feast; they are "just added for fun":

Example 9. Adventurous carnival in Kirov

The demons from the woods have stolen the poor carnival lady. Maybe it does not sound too scary, but the spring will not come before carnival is over. Today our guests will become brave heroes. They will have to fight kikimora (the spirit of the house) and to struggle with leshiy (the spirit of the woods) and prove their courage. There are many battles, games and competitions in the program: a sack race, tug-of war, funny basketball, and running with crepes on your head. Skomorokhi (folk comic actors), will entertain you and make jokes, and you will enjoy a cup of tea in a warm tent. All day long you can ride a sled and horses as long as you want. 
Another type of theatrical celebration is put into Saint Petersburg settings:

Example 10. The Empire Carnival in Saint Petersburg

You will spend three days in a splendid city where each corner is admirable.

In addition to an excursion to Pavlovsk, the eighteenth-century gem, the Empire Carnival is waiting for you. We'll see and try the emperor's fun. You'll ride a troika, and then there will be a carnival feast in a hut, which will give you a chance to learn the details of this happy feast - the way peasants used to celebrate it. A meal cooked according to ancient recipes including crepes and a musical competition is waiting for you.

There are also tourist destinations with authentic carnival performances maintained up to the present day, exactly as they are advertised in the spam letters inviting people to the Honey Carnival in Kolomna, the Souzdal street carnival, Vologda, Veliky Novgorod, and others:

Example 11. Shrovetide in Veliky Novgorod

We invite you to celebrate carnival in one of the oldest towns of Russia: Veliky Novgorod. The Novgorod area will offer you a magic celebration you will remember forever. You will make a fire and burn the figure of Maslenitsa, you will dance and fight. You will eat crepes and drink herbal tea. You will be served alcohol.

On 23 February 2012, during Shrovetide week I accepted an invitation in a spam letter and went to Pereslavl. I had a combined tour with excursions to two monasteries and three churches, to Lake Pleshcheyevo, where Peter the Great tried out his first fleet, and to the blue stone connected with many local legends, magic practices, and beliefs. The major attraction was the carnival performance in a specially constructed "House of Berendei." " The performance

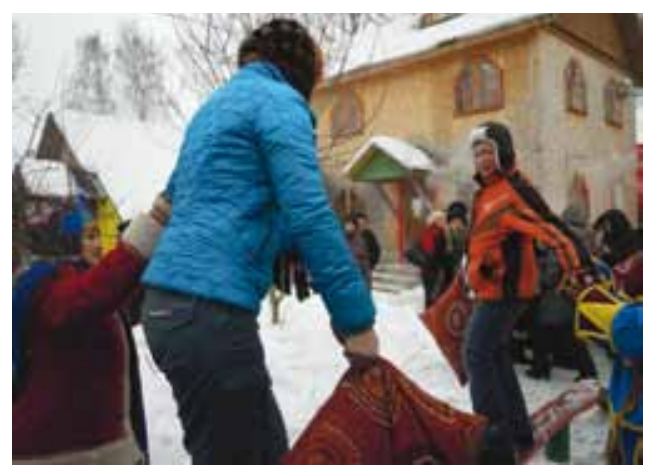

Figure 6. The Shrove-tide entertainments in The House of Berendei. Pereslavl' Zalesskiy. February, 23, 2011. consisted of very traditional ritual acts and entertainment, compiled by experts in folklore and performed by professional actors and some local people. We played games, listened to spring calendar songs, danced, and at the end burned the figure of carnival (Maslenitsa; Figures 6 and 7). Some didactic elements were incorporated the performance, such as explaining the terms and the ritual acts of each day of the Shrovetide week, teaching some games, and so on. This is an important issue for such ethnographic tourism because

7 Folklorists do not regard Berendei as a hero of the Russian mythological pantheon, but he is still very popular in literature and modern folklore. For more, see http://dom-berendej.ru/. 


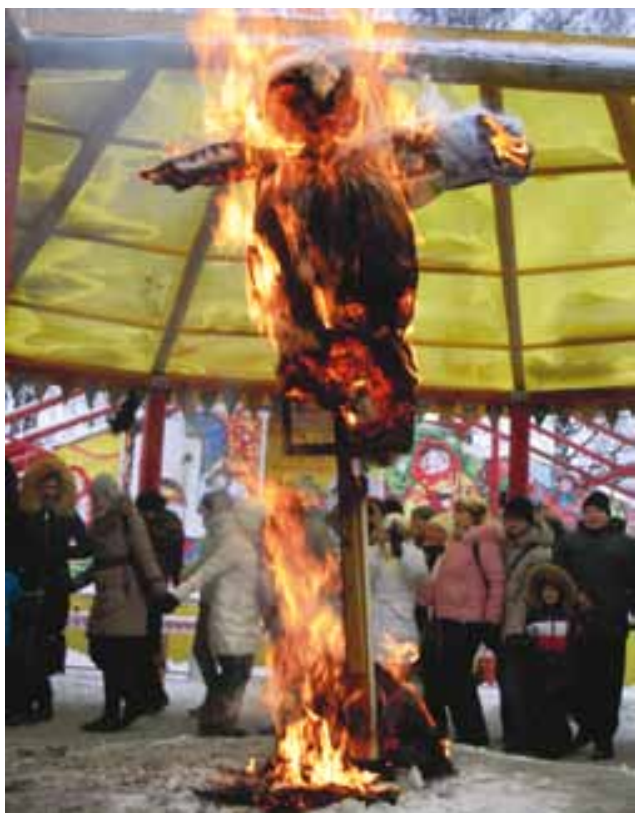

Figure 7. The figure of Carnival on fire. The House of Berendei. Pereslavl' Zalesskiy. February, 23, 2011.
Russian urban culture has forgotten the traditional feasts, and not only children, but their parents and even grandparents have (and are eager) to study folk heritage.

Apart from traditional seasonal performances of carnival, other types of entertainment are offered in the spam advertisements. The joy of eating crepes is always stressed in the letters, and tourists can choose the scenery for this culinary experience according to their interests, time, and means. Carnival can be celebrated in Shakhmatovo, the ancient country estate of the writer Alexander Block, in the city of Klin, the birthplace of the composer Peter Tchaikovsky, and so on. Here is a letter inviting participants to celebrate carnival in Pushkin's memorial places, which offers cultural and informative tourism along with ethnographic tourism:

Example 12. Shrovetide in the lands of Pskov: Pushkin's memorial places

We will visit Pushkin's memorial places, the Pushkin family estate. We will visit the house of Pushkin's nanny Arina Rodionovna, the estate of the forefather of Alexander Pushkin, Abram Hannibal, and the core of the expedition will be the Shrovetide celebrations in the city of Old Izborsk.

With the development of tourism sites, the array of offers to celebrate carnival is growing in number and detail. Some of them involve very foreign ideas, alien to Russian popular tradition, such as a carnival with crepes in an Indian village for children, and so on.

\section{THE RITUAL YEAR IN TOURISM ADVERTISING}

Apart from carnival, the church and the folk religious versions of Easter with its specific culinary treats (special cakes and cheese), games with painted eggs, and competitions offer a lot to a creative tourism entrepreneur. Almost all the tourist destinations have adjusted their programs to place the Easter celebration into the local setting, which I could see in the spam letters I received. ${ }^{8}$ In 2005, after Easter a long period of non-seasonal and eth-

8 The spam letter depicting the Easter tour to the city of Murom (example 4) adds one sentence: "On Easter you will receive some holy water in the old chapel and eat Paskha food." 
nographic letters followed, until New Year 2006 and then "the gender month" came: St Valentine's Day, 23 February (Defender of the Motherland Day, or Men's Day) and 8 March (International Women's Day). Marked dates with socialist associations, such as 1 May and 7 November, have not been used to attract tourists for celebrating, but only for cultural, ecological, or religious trips. Consequently I documented filling in the gaps in the course of the ritual year. Every year brought some new calendrical developments, which aimed to fill in the lacunae, adapting the traditional and new calendar feasts to the needs of tourists.

This process went in two directions. On the one hand, many church holidays were "privatized" by tourism agencies and destinations. On the other hand, the former Soviet holidays regained their popularity, partly out of nostalgic feelings in society and partly through the interest of the younger generations.

The church celebrations have been popular in pilgrimage tours, which followed the Christian calendar. For the other types of tourism, such as ethnographic and culinary tourism, not all the Christian Orthodox feasts were regarded as "convenient" or "interesting." Ethnographic tourism needs action and performance, and one can find these features in the folk version of the Christian calendrical feasts. Thus my e-mail inbox received advertisements for tourist trips on Midsummer Day (the Nativity of John the Baptist, 7 July, new style). In Russia this is known as Ivan Kupala (from Slavic *kup- 'to bathe') and is a rich ritual complex connected with water, fires, herbs, games and flirting for young people, and so on.

Example 13. The night of Ivan Kupala (Midsummer). The night of love The most fashionable weekend of this summer. A night full of love games and entertainment. We guarantee shows and fun until the morning. Mermaids and leshij (a forest demon), the Tambov wolf, and the witch will celebrate with you. You dance around a fire surrounded by feasting and the southern night. You take the Neoplan bus on Friday evening and by nighttime you reach the Tambov forest hotel with comfortable rooms, looking at the pine forest's clear air, you'll have meals in a summer restaurant. You'll have excursions to the Tambov Wolf museum and the Spaso church, a trip to the village of Trigulyay, Ataman Antonov's homeland. You'll visit Saint John's monastery, the chapel, you'll bathe in the holy spring and have a picnic near the Tsna River. We promise you relaxation and swimming and a night full of love and fun. On Sunday evening you will return to Moscow beloved and surrounded by new friends.

Another celebration that includes games and can be placed in the natural environment is Whitsunday, whose date changes according to Easter. In 2009, I received a spam invitation to visit Tver for Whitsunday. I made an internet enquiry, which led me to an article titled "Tourism in Tver Can Be Saved by Folklore, Whitsunday's Folk Entertainment” (http://www.rusculture. $\mathrm{ru} /$ ? $\mathrm{p}=$ thview\&id=287). This proves the idea that the development of tourism destinations greatly relies on folklore and rituals while making the calendar of excursions more condensed. 
The month of August, which used to be an "empty" period for ethnographic calendrical tourism, provides another example. The study of folk rituals probably gave entrepreneurs ideas to insert August celebrations into the development of tourism as well. In the Russian vernacular religious tradition, the three August church calendar celebrations are known as the First (Honey) Feast = the Savior (The Day of the Holy Cross, 14 August), the Second (Apple) Feast (Transfiguration, 19 August), and the Third (Rye, Bread, Nuts) Feast (The Savior on Canvas, 29 August, the day after the Dormition of the Virgin, 28 August). As can be seen from the names, the feasts allude to the fruit of nature and, because food is well exploited by ecological and culinary tourism, these feasts started to be included in the ritual tourism year.

An exclusively interesting example of the reciprocal influence of tourism entrepreneurship and governmental policy on the basis of the Russian Christian Orthodox calendar and folk religion is supplied by the case of a local church feast in Murom. I have already quoted a spam letter inviting tourists to visit this city to venerate the relics of the saints Peter and Theuronia, regarded as family patrons that can guarantee luck in romance and family life. A local legend and feast developed into a national myth and state holiday established in 2008 (the Year of the Family) as the Day of Family, Love, and Fidelity (for more on this holiday, see Sedakova, in press). The idea of using this local celebration for a Russia-wide holiday was coined in the Russian State Duma (the lower house of the Russian Parliament), and the scenario for the festival was officially launched by Svetlana Medvedeva (the Russian first lady) with huge support from mass media and governmental structures. It became a success, unlike the other important innovations in the modern Russian ritual year: 4 November and 12 June (Sedakova 2007).

The second trend making the tourist ritual year more diverse is the revitalization of the Soviet celebrations and their adjustment to tourism demands. The process of erasing the communist past has been replaced by a trend to accept Russians' nostalgic feelings. The spam letter below offers an unforgettable 1 May celebration, which combines Soviet and post-Soviet joys.

Example 14. What is the best way to celebrate 1 May

The cruise ship will welcome you with the poster "Peace Labor May." You will be captivated by a whirlpool offun and colors, just as in your childhood. Every guest will receive a personal "1 May $50 \mathrm{~g}$ vodka shot" and a very tempting herring appetizer. The tour's hour-long ride will include a boys'spy competition. Anyone can volunteer to beat the drums or play the horn. We will remind you how to tie a pioneer tie and will teach you how to do the Yablochko dance. There will be other competitions not very Pioneer-like, but rather original, such as tossing peanuts into a beer mug, poetry competition for the best holiday slogan, and a poster-making competition. You will be able to recall all of it and perhaps your children will see what it was like for the first time.

Some of the excursions offered by the tourist agencies through the spam letters are really exclusive and deal with the postmodernist humor about Soviet ideology and heroism. The 
text below timed for 23 February, the Day of Men, alludes to the legendary Russian hero Ivan Susanin, who led Polish enemy troops into the marsh near Kostroma and died with them in the seventeenth century. The Susanin route as advertised in the spam sounds very suspicious, but, of course, it is just a game, adjusted to the local nature and historical and folklore facts. The major theme is expressed in other attractions of the tourist destination that do not have a "seasonal" touch. Thus the plan of the excursion illustrates the mixture of attractions of a historical, cultural, religious, and culinary character.

Example 15. 23 February: The Day of Russian Men

The most important man of the country, Ivan Susanin, is expecting you to join him for the celebration of the 23 February. This is an adventure tour to walk the path of Ivan Susanin.

We've prepared a sightseeing program for you. These places are connected with the great history of the Russian state. In glorious Yaroslavl you will witness the great architecture of the Posad churches. Visit the Spasov monastery and also spend some time in the famous "Music and Time" museum owned by famous Yaroslavl hypnotist John Mostoslavsky.

You will spend the second day in Kostroma, guided by Ivan Susanin himself to the marsh where the Polish enemy drowned. On our way we will be stopping by the famous villages where the future Mikhail Romanov once lived. The Issupov Swamp, into which Susanin led the Poles. In Susanin's village of Savrasov, a famous artist has painted the famous landscape The Rooks Have Arrived. We will be staying in the unique place Karabikha next to Nekrasov's country estate in the modern Yaroslavl park hotel, Eurostandard bus.

The new post-Soviet state holidays 12 June (Independence Day, or Russia Day) and 4 November (Day of National Unity) have not added any interesting content to the tourist calendar. The red days in the calendar allow tourism entrepreneurs to use the longer weekends for the commercial needs of the business. In modern Russia these state festivities fall into the range of "empty," meaningless festivities that are purely ideological. Most people in the Russian Federation do not remember the precise names and the historical reasons for them, and always have a nice surprise when, for example, on 12 June they realize that they do not have to go to their offices. ${ }^{9}$ Thus the old meaning of a holiday (Russian prazdnik) 'empty, not busy day' (Toporov 1980) is restored to its literal meaning.

9 The beginning of November has been marked as a festive period because the day of the October Revolution, 7 November, has been celebrated for many decades in the USSR and is well remembered by many generations. This is, by the way, one of the strategies of restructuring the official ritual year in post-Soviet countries: to more or less keep the date of the communist holiday, but fill the celebration with new ideological (historical) content (Sedakova 2008). 


\section{FOLKLORE, THE RITUAL YEAR, AND TOURISM}

I use the case of New Year tourism as reflected in spam letters to analyze a sub-theme and to illustrate how a calendar feast can initiate a new strategy for attracting visitors to new destinations and also to renovate known tourism sites. The New Year marks a very specific place in the seasonal calendar of the Russians celebration. In the USSR it replaced Christmas, which was officially forbidden in the atheist country (on this topic, see Dushechkina 2012). During those seventy years, Christmas faded as a celebration, but with the re-Christianization of Russia in the 1990s Christmas in its folk version started to come back, both on the modern (25 December) and Russian Orthodox (7 January) dates. Here the difference in the Russian church calendar and the international one plays a decisive role. I am restricted here from describing it in detail, but in modern Russia the Christmas period starts on 24 December (under European influence) and lasts until 7 January-the date for Christmas in the Russian Orthodox Church. We also have two New Years: 1 January and the 13 January (old style). Of course, this long period (Russians have official holidays from 1 to 11 January) provides a vast field for celebrating and touring.

The most typical personages the Russian New Year is associated with are Grandfather Frost (Ded Moroz) and his "granddaughter" the Snow Girl (Snegurochka). One of the first ideas of using folklore images for tourism purposes was to find a homeland for Grandfather Frost. Again, I discovered this fact in a spam letter. The homeland of Grandfather Frost was declared to be Veliky Ustyug (copying the Finnish Santa Claus). This development is ascribed to the former mayor of Moscow Yuri Luzhkov, who was visiting the city of Ustyug, and he and the local mayor decided to declare this city the homeland of Grandfather Frost. Thus in 1999 the New Year hero obtained his place and the on-site works started. Now this place has attained the status of Grandfather Frost's homeland and various trips and cultural, ethnographic activities are being inspired by this idea (http://ipaattravel.narod. ru/velikijustug_main.htm). Thanks to this innovation, Veliky Ustyug is rapidly becoming one of the most popular tourist destinations, and not only during the Christmas season.

Many provincial cities followed this example. The first fairy-tale hero used as an attraction for the tourists was the famous picturesque Baba Yaga. In 2006, I received a spam letter which invited me to visit Yaroslavl, Poshekhonye, and Kukoboy:

Example 16. The most mysterious and unforgettable trip in your life We invite you to come with us to Baba Yaga's house in the very middle of the woods, the homeland of Baba Yaga. She will welcome you with pirozhki, and you will drink tea served from a samovar. You will buy good souvenirs: Baba Yaga's hut, and so on.

In 2004, the village of Kukoboy declared itself the homeland of Baba Yaga, but there are other places that compete for this privilege, like the village of Staritsa in the Tver region, 
Kuban' (ataman') and others. The explanations for the choice of the native place of a hero, a demon, or an evil spirit vary a lot. The homeland of the famous heroes of the Russian fairytale, the sister Alyonushka and brother Ivanushka, for example, has been declared to be the village of Ryabovo - the native place of Mikhail Vasnetsov, the Russian artist and creator of the well-known illustration of these heroes. Kolobok (a small round loaf of bread) was "born" in Ulyanovsk because, as local dialectologists insist, there are such words in the local dialect. The pseudo-mythological personage Kostroma (the spirit of nature and spring) undoubtedly comes from the city of Kostroma, and so on. Sometimes there is no reason at all; just the rule "First come, first served" works; thus Kirov turned into the native place of Kikimora ${ }^{10}$ (a female spirit of the house), vodyanoy (the spirit of the water) is said to live in Poshekhonye, and so on.

Folklore and tourism is a vast subject, rich with material, still under construction, very appealing for further research. What is important $\mathrm{n}$ this article is that whenever a fairytale hero or a spirit obtains a native place, it starts to develop a personal ritual year that is immediately used in tourism advertising. Thus on the last Saturday of June tourists are invited to join Baba Yaga's birthday party, Kikimora celebrates her birthday on 2 March and her wedding anniversary with Domovoy (the male spirit of the house) is on 15 May. There is a special date in the ritual year of Vodyanoy: he wakes up on 16 April and a special performance is given for tourists.

The images of the Russian folktales and mythology used as local brands give the advertising agencies and municipal authorities excellent opportunities to develop the city, to create its local identity, to provide the local people with work (for crafts, catering, accom-

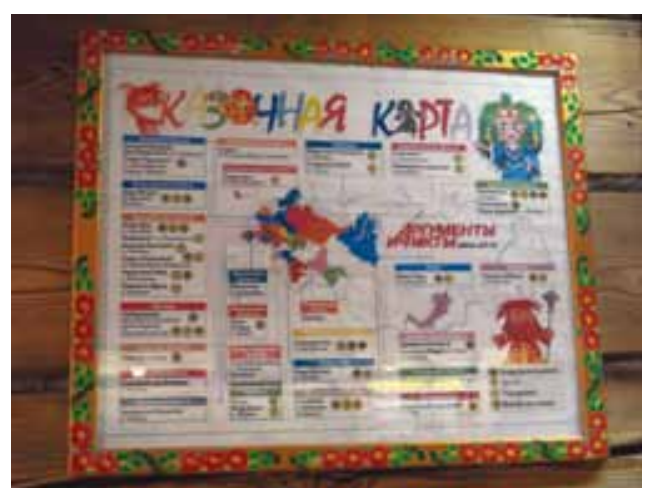
modation, etc.), and to attract growing numbers of tourists. The process of privatizing the heroes and the demons moved to the state level when the project Fairytale Map of Russia was launched in November 2010, and a special network of tourism and other advertising agencies and municipal authorities was established. ${ }^{11}$

Figure 8. The Fairy-tale map of Russia in the corner of thematic ritual souvenirs in The House of Beredei. February, 23, 2011.

10 Some local historians insist that there are some toponyms with the name of Kikimora near Kirov.

11 The participants in this huge project come to visit each place of folklore tourism and discuss plans. Each participant comes with a thematic gift; these are collected and then displayed in a special corner of a museum, as in Pereslavl (Figure 8). 


\section{CONCLUSION}

Analysis of the spam advertising of tourism illustrates that the passage from the Soviet ideas and way of life to a very new stage, post-Soviet (which still does not have a proper name), is interesting for researchers and is vivid on a large and small scale. The spam letters show new attitudes toward time and space, toward history and memory, toward the past, present, and future, toward the idea of Russianness, and toward serious and entertaining issues.

One can also see that the values of folk culture and heritage as a whole have regained their power and served as a very important tool in commerce and in the ideological formation of identity and Russianness. The observations of European and American anthropologists (Hobsbawm \& Ranger 1983; Boissevain 1992; Lowenthal 1998; Fournier 2008) that analyze the processes of (re)inventing tradition are now very topical for Russia and for other post-socialist countries [Habinc 2008; Volarič 2008), which are going through the complicated process of regaining national identity after several decades of being in the communist bloc and are now facing globalization. The process of commercializing rituals and assigning them to seasons, as has been seen, also has partly positive outcomes because it suggests didactic, archival, and research activity.

When talking about folklore, the ritual year, and tourism, special attention has to be paid to notions of entertainment and relaxation, which have turned into the key slogans nowadays. Some scholars define entertainment as the epidemic of our days (Odinokova 2006). The Russian is sometimes seen as Homo feriens, the 'celebrating person' (determined by the semiotician Vladimir Toporov, 1980). Russian society is trying to fill in the vacuum and gaps that formed as a result of de-ideologization and looking for new rituals, faith, and restoration of heritage. David Lowenthal commented on a similar situation: "The creed for heritage answers needs for ritual devotion, especially where other formal faith has become prefunctonary or mainly political" (1998: 1-2). Russia has not reached the state of "craze for heritage" at the official and individual levels, but the craze for folklore and ritual, especially calendrical feasts that bring joy and relaxation, is in the air.

\section{REFERENCES}

Boissevain, Jeremy

2007 Saints, Fireworks, and Tourists. In: Nash (ed.): The Study of Tourism, Anthropological and Sociological Beginnings. Oxford: Elsevier, 33-49.

Boissevain, Jeremy (Ed.).

1992 Revitalizing European rituals. London \& New York: Routledge.

Cole, Stroma

2008 Tourism, culture and development: hopes, dreams and realities in East Indonesia.

Clevedon: Cromwell press. 
Dallen, J. Timothy

2011 Cultural heritage and Tourism: An Introduction. Aspects of Tourism Texts: Channel View Publications.

Dallen, J. Timothy \& Stephen W. Boyd

2003 Heritage tourism. Pearson Education Limited.

Dann, Graham

1996 The Language of Tourism: A Sociolinguistic Perspective. Massachusets: CAB International.

Dann, Graham (ed.)

2002 The Tourist as a Metaphor of the Social World. Ed. Dann G.M.S. New York: CABI Publishing.

Dushechkina, Elena V.

2012 Russkaja elka: Istorija, mifologija, literatura. Sankt-Peterburg: Evropejskij Universitet.

Fournier, Laurent $S$.

2008 The claim for history in contemporary calendar festivals:

legendary, historical and present times. The Ritual Year and History (The Ritual Year 3). Stražnice: Lidova kultura.

Graburn, Nelson H.H.

1998 Tourism: the sacred journey. Hosts and Guests. The Anthropology of Tourism: 21-36. Pennsylvania: Univ. of Pennsylvania press.

Gurin, Stanislav P.

2004 Turizm kak antropologicheskij fenomen. Topos. Literaturno-filosofskij zhurnal. 23/03/2004. http://www.topos.ru/article/2169

Habinc, Mateja

2008 Raziskave (post)socialističnih koledarskih praznikov. Traditiones: 79-98. 1 (37). Ljubljana.

Hobsbawm, Eric \& Terence Ranger (Ed.)

1983 The invention of tradition: Cambridge university press.

Lowenthal, David

1998 Crusade and the spoils of history: Cambridge University Press.

Nash, Dennison

1996 Anthropology of Tourism. Pergamon

Nash, Dennison (ed.)

2007 The Study of Tourism. Anthropological and Sociological Beginnings. Oxford: Elsevier.

Odinokova, Ljudmila Ju.

2006 Razvlechenija - jepidemija sovremennogo mira. In: Bremja razvlechenij: Otium v Evrope, XVIII - XXvv/Red.-sost. E. V. Dukov. Sankt-Peterburg: Dmitrij Bulanin.

Santino, Jack

1996 New old-fashioned ways: holidays and popular culture. Knoxville: University of Tennessee Press.

Sedakova, Irina

2008 Inventing the Ritual Year in Modern Russia. The Ritual Year and History (The Ritual Year 3): 51-58. Stražnice: Lidova kultura.

2009 Tradicionnaja i massovaja kul'tura v Internete citaty, kvazi-citaty $i$ alljuzii. Folk-art-net: novye gorizonty tvorchestva. Ot tradicii k virtual'nosti. Sbornik statej: 270-284. Moskva.

2010 Fol'klor, cennosti i kommercija ( na materiale cvetochnyh mifov v SMI i Internete). Ot kongressa $k$ kongressu. Materialy Vtorogo Kongressa rossijskih fol'kloristov: 91-98. Moskva.

In print Weddings and the Ritual Year in Modern Russia. In: The Mask. The Ritual Year 5 / Ed. Vaicekauskas, Arunas. Kaunas. 
Smith, Laurajane, Waterton, Emma \& Steve Watson (Eds.).

2012 The Cultural moment in tourism: Routledge.

Smith, Valene S. (ed.)

1989 Hosts and Guests. The Anthropology of Tourism. Pennsylvania: Univ. of Pennsylvania press.

Toporov, Vladimir

1992 Peterburgskie teksty i peterburgskie mify (Zametki iz serii). Sbornik statej $k$ 70-letiju prof. Ju.M.Lotmana: 452-485. Tartu.

1980 Prazdnik. In: Mify narodov mira: Jenciklopedija. T. 2. S. 329-331. Moskva: Sovetskaja jenciklopedija.

Volarič, Tina

2008 Pustovanje. Ločnice in prehodi. Traditiones 37, 1: 47-78.

\section{RUSKO PRAZNIČNO LETO IN FOLKLORA V TURISTIČNEM OGLAŠEVANJU}

Raziskava sodi v sfero antropologije turizma in upošteva različne kulturne, religiozne, politične in delno tudi ekonomske procese $v$ moderni Rusiji. Osnovni vir podatkov za raziskavo so turistični oglasi, ki so kot nezaželena elektronska pošta krožili med letoma 2005 in 2012. Izražajo namreč komercialne in ideološke težnje in vodilne tokove prestrukturiranja prazničnega leta in posovjetskega prostora. Po razpadu ZSSR so ruska folklora in koledarske ritualne prakse znova pridobili status nacionalne večvrednosti. Revidiran je bil tudi koncept kulturne dediščine, pomembne za identifikacijo in idejo "ruskosti«. Začel se je proces ustvarjanja »staro--novega "ruskega ritualnega - prazničnega časa in svetega prostora. Najprivlačnejša koledarska praznovanja so za turistične namene postala tista, ki so povezana s hrano, z zabavo in uprizoritvami. Primer "maslenice" $m$ tj. pusta, analiziranega v tej razpravi, razkriva možnosti, ki jih prazniku ponuja lokalno okolje. Prikaže tudi raznolike variante ritualnega kompleksa - od avtentičnega do izmišljenega scenarija, namenjenega zabavnejši in bolj interaktivni zabavi. Vsak geografski prostor si želi pridobiti ritualni status in - delno zaradi naraščajoče turistične industrije - biti povezan s koledarskim praznikom, pomembno zgodovinsko ali folklorno osebnostjo ali s čim podobnim. Tako je Dedek Mraz dobil svoje domovanje v Velikij Ustiug, Jaga baba v vasi Kukoboj, Mišv mestu Myshkin (miš) itn. Razlage za izbiro prostora bivalǐ̌ča junaka ali demona so različne, pogosto temeljijo na lingvističnih ali samo na izmišljenih razlogih. Ko se junak spremeni v blagovno znamko provincialnega mesta, podjetniki začnejo sestavljati osebno praznično leto tega junaka, da bi privabili več turistov. Etnografski koledarski turizem pridobi tako nove razsežnosti.

Decembra 2010 je nacionalni projekt "Pravljični zemljevid Rusije "prevzel prvotno naključne lokalne dejavnosti, nadzor nad ponovnim iznajdevanjema mitologije lokalnih prostorov pa je prevzela vlada.

Prof. dr. Irina Sedakova. Institute for Slavic Studies. Russian Academy of Sciences, Leninsky prospect 32A, 117334 Moscow, Russia, irina.a.sedakova@gmail.com 